\title{
Alkalinizing Agents: A Review of Prescription, Over-the-Counter, and Medical Food Supplements.
}

\author{
Karen L. Stern \\ Mayo Clinic \\ Noah Canvasser \\ University of California Davis \\ Michael Borofsky \\ University of Minnesota \\ Vanessa M. Gleason \\ Thomas Jefferson University \\ Fuld, Kamphudis ditional works at: https://jdc.jefferson.edu/tjuhpapers \\ $\triangle M C$ \\ Part of the Medical Pharmacology Commons, and the Urology Commons \\ Let us know how access to this document benefits you
}

\section{Recommended Citation}

Stern, Karen L.; Canvasser, Noah; Borofsky, Michael; Gleason, Vanessa M.; Kamphuis, Guido; El Tayeb, Marawan M.; Hsi, Ryan; and Scotland, Kymora B., "Alkalinizing Agents: A Review of Prescription, Over-the-Counter, and Medical Food Supplements." (2020). Jefferson Hospital Staff Papers and Presentations. Paper 18.

https://jdc.jefferson.edu/tjuhpapers/18

This Article is brought to you for free and open access by the Jefferson Digital Commons. The Jefferson Digital Commons is a service of Thomas Jefferson University's Center for Teaching and Learning (CTL). The Commons is a showcase for Jefferson books and journals, peer-reviewed scholarly publications, unique historical collections from the University archives, and teaching tools. The Jefferson Digital Commons allows researchers and interested readers anywhere in the world to learn about and keep up to date with Jefferson scholarship. This article has been accepted for inclusion in Jefferson Hospital Staff Papers and Presentations by an authorized administrator of the Jefferson Digital Commons. For more information, please contact: JeffersonDigitalCommons@jefferson.edu. 


\section{Authors}

Karen L. Stern, Noah Canvasser, Michael Borofsky, Vanessa M. Gleason, Guido Kamphuis, Marawan M. El Tayeb, Ryan Hsi, and Kymora B. Scotland 


\section{TITLE: Alkalinizing agents: a review of prescription, over-the- counter, and medical food supplements}

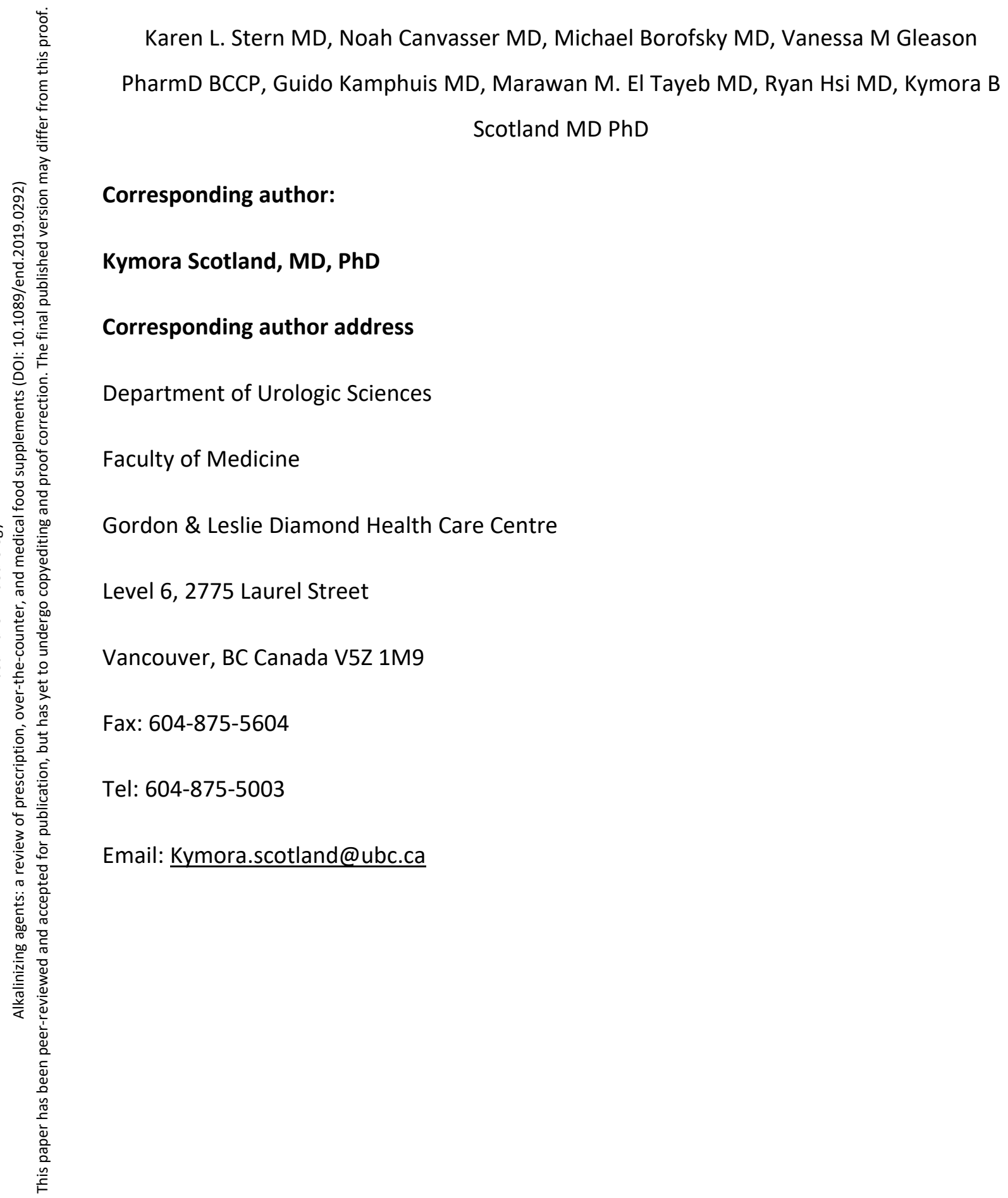


Page 2 of 22

Co-Author addresses:

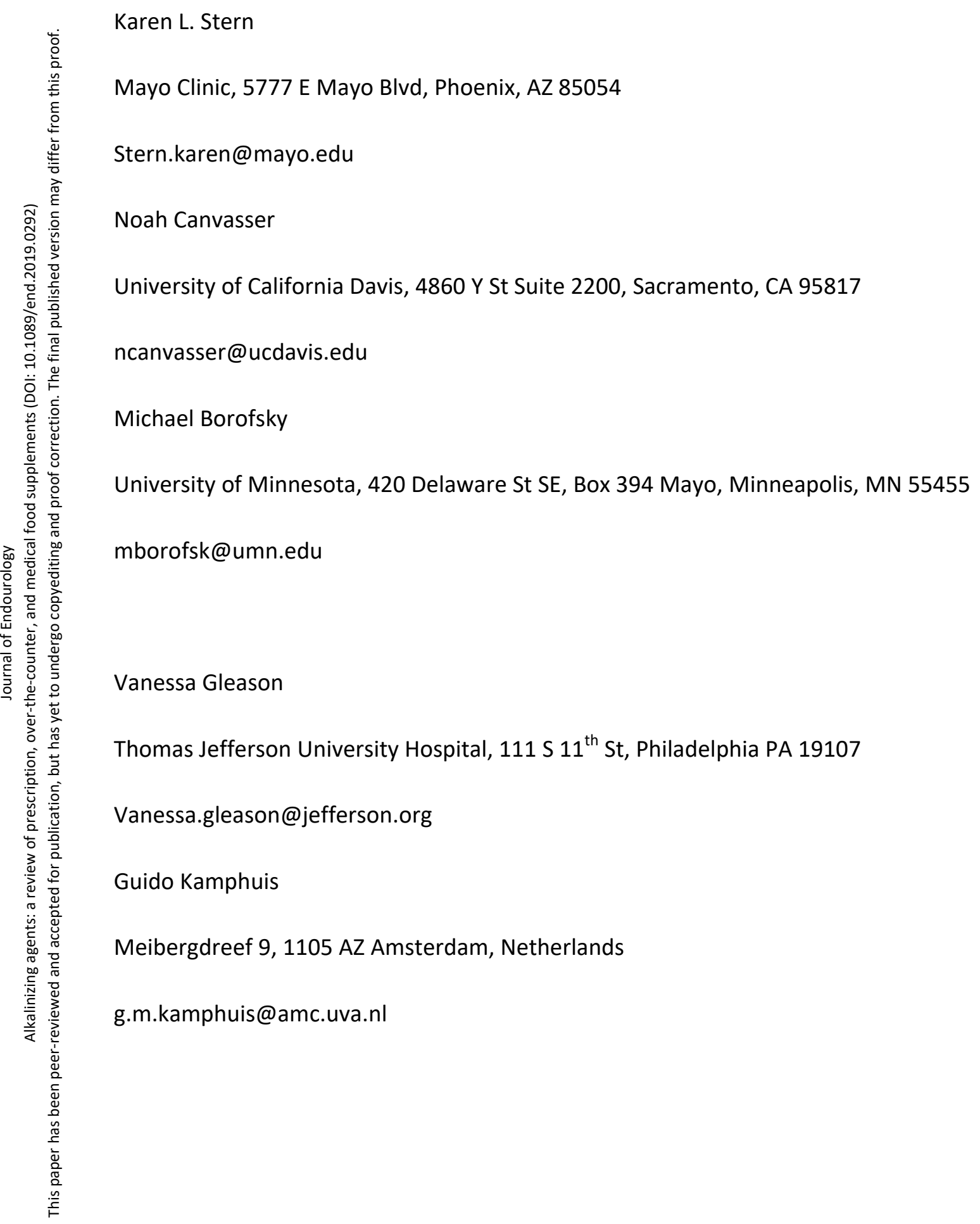


Marawan El Tayeb

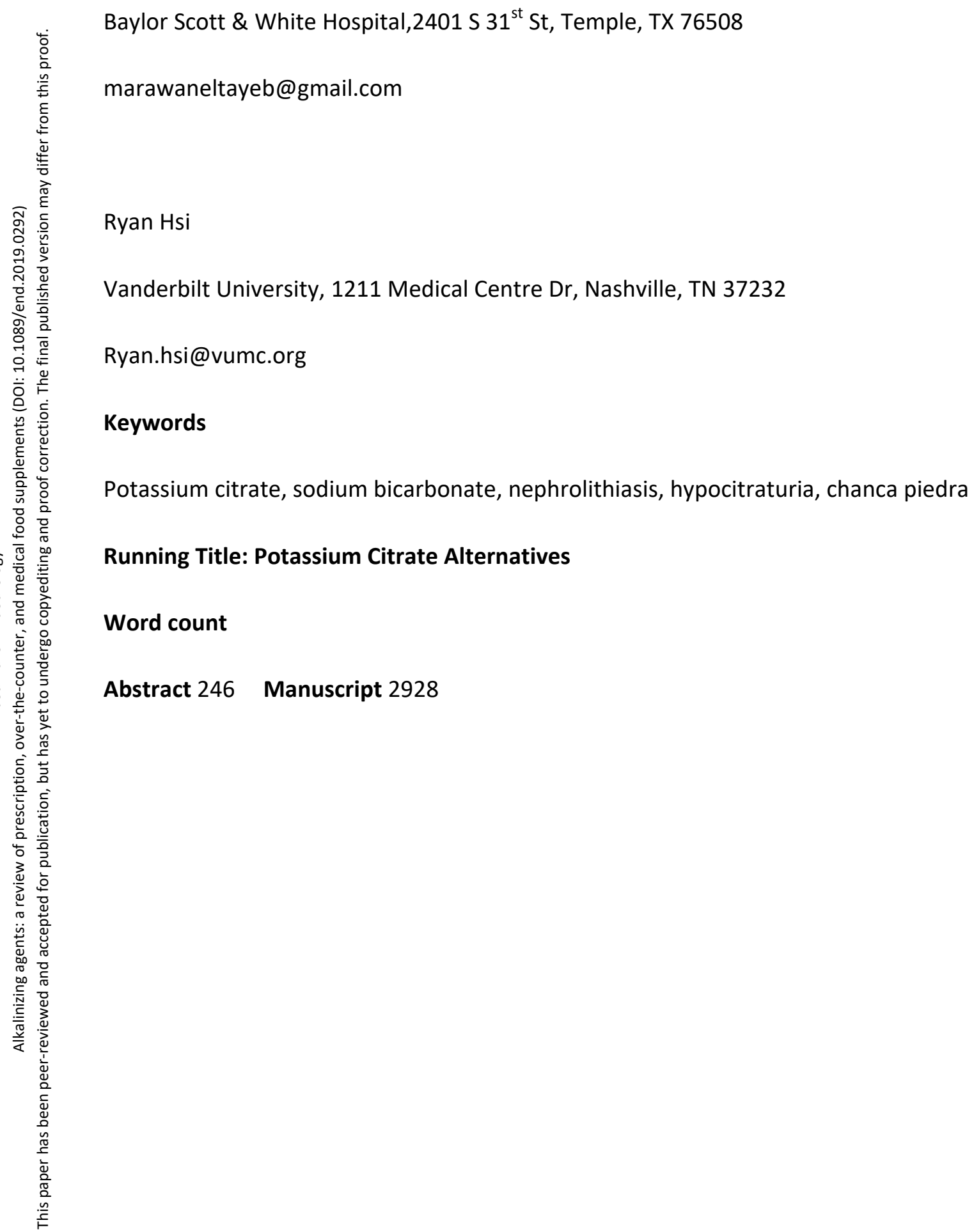




\section{ABSTRACT}

\section{Introduction}

Kidney stones affect 1 in every 11 people in the United States each year. There is a significant high recurrence rate without a stone prevention protocol. Alkali citrate is beneficial in decreasing stone recurrence, but due to the cost and gastrointestinal side effects there is a low adherence rate. This study aims to serve as a review of some of the most commonly used alkalizing over- the- counter supplements that are advertised to prevent and treat kidney stones.

\section{Methods}

Data was gathered by a comprehensive online literature search and company inquiries for kidney stone prevention supplements. An additional informal poll of the authors selected supplements that are most commonly taken by their patients. A total of eight supplements were evaluated for cost, alkali equivalent provided, dosing and regulatory information.

\section{Results}

Eight of the most commonly used supplements were reviewed with a focus on alkalizing agents. Information reviewed revealed dosing recommendations resulting in decreased citrate alkali equivalents per day compared to prescription-strength potassium citrate. Cost, peer-reviewed study results and regulatory data were reviewed, tabulated and analyzed. Cost per alkali equivalent was substantially decreased for each supplement compared to the prescribed drug. All supplements were found to be readily available online.

\section{Conclusion}

Over- the- counter alkalizing agents are available to patients and may be an appropriate alternative to cost prohibitive potassium citrate when treating urolithiasis patients. Additional testing will be necessary in the future to determine the efficacy of these supplements in the treatment and prevention of urinary stone disease. 


\section{INTRODUCTION:}

Kidney stones affect 1 in every 11 people in the United States each year. ${ }^{1}$ Unfortunately, without dietary and/or medical management kidney stones can have a significant recurrence rate, highlighting the importance of prevention. ${ }^{2}$ The American Urological Association (AUA) guidelines recognize the effectiveness of medical management at decreasing the recurrence of stone disease and recommend that clinicians offer pharmacologic therapy to recurrent stone formers. ${ }^{3,4}$ Several clinical trials have demonstrated the effectiveness of potassium citrate in decreasing stone recurrence. 5,6 However, among kidney stone patients prescribed potassium citrate for stone management, only $13 \%$ are adherent with the medication. ${ }^{7}$ Low adherence to stone preventative therapy is likely multifactorial. Side effects associated include abdominal pain and diarrhea. ${ }^{9}$

Another significant barrier to medication adherence is its cost. Potassium citrate retails at an average cost of $\$ 154.80$ for a one-month supply of the generic formulation at a dosage of 15 milli equivalents (mEq) twice daily (BID). ${ }^{10}$ This is notable considering that the urine alkalinization is a long-term therapy. Anecdotally, patients often report insurance formularies do not cover commonly prescribed potassium citrate formulations. The combination of the effectiveness of the medications with the prohibitory cost of the prescription has led to the development of multiple over-the-counter supplements that promise to alkalize the urine and/or decrease the risk of future kidney stones.

A simple Amazon search for "kidney stone medicine" returns more than 250 results. Although the manufacturing of over-the-counter options is not regulated, and many are not scientifically tested to the same degree as prescribed alkali citrate, they may be effective and the affordability may increase patient compliance and adherence.

We review the more common over-the-counter supplements advertised to prevent or directly treat kidney stones, specifically focusing on alkalizing agents. The intent of this review is to educate providers on the supplements available to their patients, especially patients who frequently self-educate and self-prescribe without direct oversight from the treating physician. Shared decision making is a critical part of a patient-provider 
relationship, and knowledge of treatment options beyond the standard prescriptions is essential in strengthening that relationship. While the goal of this review is not to promote or advertise for any of the described supplements, a baseline knowledge of these options may prove useful in the event patients inquire about them or self-administer.

\section{Urinary Alkalization}

The common Western diet includes a large acid load, predominantly from animal protein intake. In the kidneys, acid loads cause increased citrate uptake in renal cells leading to lower urinary citrate and increased supersaturation of calcium salts. Urinary citrate is thought to decrease stone recurrence by complexing with calcium in the urine, which increases the solubility and reduces the concentration of free calcium in the urine, as well as by binding the surface of crystals to prevent agglomeration and growth. ${ }^{8}$ In vitro, citrate has been shown to inhibit calcium oxalate precipitation and decrease calcium phosphate growth. ${ }^{11,12}$ Hence, alkali supplementation to raise urine $\mathrm{pH}$ and limit urine citrate uptake is recommended for stone formers with low urine $\mathrm{pH}$ and/or urinary citrate. ${ }^{4}$

Multiple ingestible forms of alkali exist. Baseline knowledge of urinary alkalization is important when reviewing over-the-counter alkali preparations. The most commonly prescribed alkali for stone prevention is potassium citrate, which has demonstrated as high as a $75 \%$ risk reduction of kidney stone recurrence, with a long-term durable response in some patients. ${ }^{13,14}$ Although similar, citric acid, a protonated form of citrate, is less effective at increasing urinary citrate due to the counterproductive acid load. ${ }^{15}$

These differences have potential significance when dietary beverages are being used to prevent stones. For example, lemonade therapy is commonly recommended to stone formers as a way to increase urinary citrate. Orange juice, however, may in fact be more effective given a greater portion of potassium citrate versus citric acid. ${ }^{16,17}$ Coconut water, due to a large malate as alkali component, can also increase urinary citrate if ingested in large quantities. ${ }^{18}$ In addition, some citrus-flavored carbonated beverages also contain large portions of alkali due to citrate and malate content, however, substantial volumes of these beverages would need to be ingested to match the alkali content of prescribed potassium citrate. ${ }^{19}$ 
Bicarbonate is another useful alkali, with both sodium bicarbonate and potassium bicarbonate demonstrating similar efficacy to potassium citrate at raising urine $\mathrm{pH}$ and urine citrate. ${ }^{20,21}$

The cation associated with each alkali salt can have important consequences. Sodium administration can increase blood pressure and decrease bone mineral retention. Most importantly for kidney stone patients, it has a hypercalciuric effect that can be counterproductive. ${ }^{20}$ Magnesium citrate also increases urine $\mathrm{pH}$, but is associated with significant gastrointestinal effects which can counterproductively increase urinary oxalate through malabsorption. ${ }^{22}$ Additionally, magnesium can decrease intestinal absorption of oxalate. Lastly, potassium lowers urine calcium and increases urine citrate ${ }^{20}$ but can be dangerous for patients with renal failure or significant cardiac disease, and therefore requires close monitoring. ${ }^{13}$

\section{Regulation}

The Food and Drug Administration (FDA) is the governing body regulating the content and sale of domestically produced food and pharmaceuticals in the United States. For approved pharmaceuticals, good manufacturing processes (GMPs) are regulated by the FDA to ensure the identity, strength, quality, and purity of drug products is maintained. Generally Recognized as Safe (GRAS) is a FDA designation that a chemical or substance is considered safe by experts. Any substance added to a food is subject to review and approval by the FDA, unless said substance is identified as GRAS.

Many over-the-counter treatments for kidney stone formers are marketed as medical foods or supplements. Per the FDA and based on the United States Orphan Drug Act, a medical food is "a food which is formulated to be consumed or administered enterally under the supervision of a physician and which is intended for the specific dietary management of a disease or condition for which distinctive nutritional requirements, based on recognized scientific principles, are established by medical evaluation". ${ }^{23}$ The FDA does not approve supplements. The United States Pharmacopeia Convention is a nonprofit organization that publishes an annual compendium of drug information, the United States Pharmacopeia (USP). In order to assure quality among supplements and protect 
consumer health, the USP works with manufacturers in an attempt to verify the quality of ingredients and products. A multi-step evidence-based process is used to confirm the accuracy of the information supporting the quality of each product being verified in a particular program. However, it is important to note that USP has no role in enforcement of these standards. Hence, manufacturer claims must be carefully considered. In particular, only supplements that have been tested and meet the USP program requirements are allowed to display the USP Verified Dietary Supplement mark. This is not equivalent to manufacturers who claim to adhere to USP standards without verification.

\section{METHODS:}

A comprehensive search for "kidney stone medications" and "kidney stone medicine" was performed on online shopping websites that are likely visited by patients (i.e., Amazon, Google). In addition, an informal poll of the authors was undertaken to determine the supplements that are most commonly taken by their patients. Product information was obtained from manufacturer websites and via company inquiries. Scientific literature search was performed via PubMed, with manuscripts reviewed and summarized in the results. Any additional available literature regarding the various products was reviewed and reported.

\section{RESULTS:}

Eight supplements were reviewed, with a focus on alkalizing agents. See Table 1 for summary of the alkali containing supplements. Commercial potassium citrate comes in three doses: 5, 10, or $15 \mathrm{mEq}$ of alkali. As seen in Table 1, most supplements provide a fraction of this amount.

\section{Pure Alkalizing Agents:}

A search for "Potassium Citrate" on Amazon returned 213 products; we reviewed three of these products. NOW Potassium Citrate is "Amazon's Choice," BulkSupplements is the most reviewed potassium citrate product with over 1400 reviews, and Litholyte was selected based on its popularity among patients. 
There are numerous versions of potassium citrate that are currently online. Two of the more commonly reviewed products are BulkSupplements (Hard Eight Nutrition LLC, Henderson, NV, USA) and NOW ${ }^{\circ}$ Potassium Citrate (NOW, Bloomingdale, IL, USA). ${ }^{24,25}$ Each of these is available as a powder. The BulkSupplements formulation has $99 \mathrm{mg}$ of potassium citrate (0.92 mEq of alkali) per serving of $275 \mathrm{mg}$ (3.33 mEq of alkali/1 gm supplement) whereas the NOW ${ }^{\oplus}$ Potassium Citrate powder has $448 \mathrm{mg}$ of potassium citrate (4.15 mEq of alkali) per serving of 1.4 grams ( $2.96 \mathrm{mEq}$ of alkali/1 gm supplement). NOW ${ }^{\oplus}$ Potassium Citrate also comes in a $99 \mathrm{mg}$ vegetarian capsule (0.92 mEq of alkali). Again, for comparison commercial potassium citrate contains between 5-15 mEq of alkali per tablet. BulkSupplements is made in an FDA-registered facility.

Litholyte (Litholyte Corporation, New Bern, NC, USA) is a powdered mixture of potassium citrate, magnesium citrate and sodium bicarbonate developed by urologist Ryan Holland, MD. ${ }^{26}$ Each packet contains $10 \mathrm{mEq}$ of alkali and the manufacturers recommend twice daily dosing (see Table). It has zero calories and is unflavored to allow incorporation into a liquid of the patient's choice. The inventors note there is no citric acid in this product leading to a net alkali effect on systemic $\mathrm{pH}$. There are currently no peer-reviewed publications evaluating Litholyte ${ }^{\bullet}$. However, the manufacturer cites studies that demonstrate the benefit of sodium bicarbonate or combination potassium and magnesium citrate versus placebo. ${ }^{25,26}$ This is not marketed as a prescription medication. It is still patent pending but has been classified by the FDA as a medical food.

\section{Combination Alkalizing and Vitamin Supplements:}

There are several available alkalizing supplements that combine citrate with vitamin B6 and magnesium including TheraLith ${ }^{\circledR}$ XR, StoneStop ${ }^{\mathrm{TM}}$, KSPTabs, Kidney C.O.P. ${ }^{\circledR}$ and Lithobalance ${ }^{\mathrm{TM}}$ TheraLith ${ }^{\circledR} \mathrm{XR}$ (Theralogix LLC, Aston, PA, USA) is a supplement that contains vitamin B6 (7.5 mg), magnesium (180 mg) and potassium citrate $(99 \mathrm{mg} / 0.92$ $\mathrm{mEq}$ ), in a delayed-release coating. ${ }^{27}$ The magnesium included is both magnesium citrate (1.2 $\mathrm{mEq}$ ) and magnesium oxide. The supplement is dye-free, gluten-free and is made in the United States. The recommended dosage is two tablets twice a day with food. A study in 2006 at Stony Brook University Hospital found normalization of urinary magnesium and 
urinary citrate levels after two months of consistent intake in patients with known low urinary magnesium and citrate. ${ }^{28}$ TheraLith ${ }^{\circledR} \mathrm{XR}$ retails for $\$ 60.00$ per bottle (90 day supply).

StoneStop (StoneStop LLC Wilmington, DE, USA) is an over-the-counter pH-neutral mixture of citrate, magnesium, and vitamin B6 in individual packets. ${ }^{29}$ StoneStop was developed by urologist Kyle Wood, MD. The dosage of each ingredient is not immediately available to consumers. Each packet is mixed into 16 ounces of water and dissolved, and the recommendation is to consume two packets daily. Like Litholyte ${ }^{\circledR}$, it is advertised as a medical food and recommended to be used under medical supervision. Since the cation complexed with citrate is magnesium, rather than sodium or potassium, the dosage may be limited by gastrointestinal side effects, specifically, diarrhea. Retail price is 30 packets for $\$ 29.99$.

KSPtabs (Austin, TX, United States) are dissolving effervescent tablets developed by urologist Michael Trotter, MD. ${ }^{30}$ Manufacturer recommendation is to consume one tablet in 16 ounces of water, 2-3 times per day. One KSPtab contains vitamin B6 (7.5 mg), magnesium (64 mg), sodium bicarbonate (170 mg/ $2 \mathrm{mEq}$ ) and potassium bicarbonate $(100 \mathrm{mg} / 1 \mathrm{mEq})$. The tablets come in two flavors, lime and berry, and are advertised as gluten-free, vegan friendly and all-natural. They are sweetened with dextrose and stevia. Each tablet is 10 calories and has 1 gram of sugar. The company has made available a selfproduced study investigating urinary parameters in 35 nephrolithiasis patients who had taken the supplement. The study found increased urinary outputs and urine $\mathrm{pH}$, citrate and magnesium with decreased urinary calcium and super saturation of uric acid on 24hour urine analysis following administration of KSPtabs. This study is available on their website. ${ }^{30}$ However, there are currently no peer-reviewed studies reported using KSPtabs to prevent kidney stones. Eighty tablets (approximately 1-month supply) retail for $\$ 59.95$.

Kidney C.O.P. ${ }^{\circledR}$ (Calcium Oxalate Protector, Calcium Oxalate Labs Inc., Ft. Lauderdale, FL, USA) is a patented formulation that combines five ingredients, each suggested to prevent stone growth. ${ }^{31}$ In addition to citric acid $(4.5 \mathrm{mEq})$, vitamin B6 and magnesium, Kidney C.O.P. ${ }^{\circledR}$ also includes Phytin and Musa Paradisiaca. Phytin (Inositol) is a known 
crystallization inhibitor of calcium salts that has been shown to have a synergistic effect when combined with magnesium in vitro. ${ }^{32,33}$ Musa Paradisiaca (Banana Stem) has traditionally been used as a natural remedy for stone prevention. Formal evidence supporting this is sparse in the literature, but proposed mechanisms include a diuretic effect as well as decreased activity of liver enzymes that are involved in oxalate production. One small series suggested efficacy when used among a rat model of ethylene glycol induced nephrolithiasis. ${ }^{34}$ The Kidney C.O.P. ${ }^{\circledR}$ website claims that in vitro testing of the patented formula led to a $99 \%$ inhibition of calcium oxalate growth rate; these findings could not be verified by peer-reviewed literature at the time of publication. Furthermore, the website's disclaimer notes that the proposed stone prevention mechanism has not been evaluated by the FDA.

LithoBalance $^{\mathrm{TM}}$ (AmPurity Nutraceuticals ${ }^{\mathrm{TM}}$, Fenton, MO, USA) is a combination of vitamin B6, magnesium citrate and potassium citrate sweetened with stevia leaf extract. ${ }^{35}$ The recommended serving size is one scoop (10 grams), dissolved in 12-16 ounces of water, 2 to 3 times daily with meals. One scoop contains $20 \mathrm{mg}$ vitamin $\mathrm{B} 6,43 \mathrm{mg}(0.6 \mathrm{mEq})$ magnesium citrate, $410 \mathrm{mg}(3.8 \mathrm{mEq})$ potassium citrate and $150 \mathrm{mg}$ Stevia leaf extract. No artificial colors, sweeteners or flavors are claimed to be added. The product is claimed to have been developed by a team of clinical urologists and research scientists. The website refers to several publications related to the effect on stone formation of potassium citrate, magnesium citrate, vitamin B6, and magnesium oxide (dihydrate). In the referenced studies, there are several combinations and dosages of these ingredients mentioned, however there is no published literature on the specific combination and quantities of the materials in LithoBalance ${ }^{\mathrm{TM}}$ in the literature, and no publications on LithoBalance ${ }^{\mathrm{TM}}$ specifically. One container contains 90 servings (approximately 1-month supply) and retails for $\$ 49.89$.

\section{Chanca Piedra- containing Supplements:}

A simple online search for "kidney stone medicine" will lead patients to dozens of products with Phyllanthus niruri (Chanca Piedra). Phyllanthus niruri (Chanca Piedra, Spanish for "stone breaker") is a plant used in both Ayurvedic systems of medicine in India and in folk 
medicine in Brazil and Peru. It is neither cytotoxic nor genotoxic. ${ }^{36}$ There are some studies indicating that Chanca Piedra has a role in decreasing kidney stones, increasing urine potassium, and decreasing urinary oxalate and urinary uric acid. ${ }^{37-39}$ However, the need for additional rigorously performed studies persists. Given that the scope of this paper is to focus on alkalinizing agents, products containing Phyllanthus niruri were not reviewed in great detail here.

\section{DISCUSSION:}

The high prevalence of kidney stone disease makes access to medical therapies a necessity for patients. Unfortunately, the high cost and side effects of prescription potassium citrate is prohibitive for many patients and results in low adherence. ${ }^{7}$ A 2013 survey found that $72 \%$ of patients look online for health information. ${ }^{40}$ Patients are likely using similar search engines to find accessible and affordable alternatives to expensive prescription medications. Providers need to be aware of these formulations to appropriately counsel patients on the risks and benefits of such therapies.

It must be emphasized that none of these products are FDA approved for the treatment of kidney stones and they have little to no scientific data to support the manufacturers' claims. In fact, KSPtabs and TheraLithXR are the only supplements reviewed here that are associated with any documented studies on the product. ${ }^{28,30}$ Litholyte and StoneStop are classified as medical foods. The medical food category became popular in the late $1980 \mathrm{~s}$ and 1990s and has grown into a lucrative business, valued at $\$ 12.3$ billion in 2015 and expected to surpass $\$ 24$ billion by $2025 .{ }^{41}$ As mentioned above, a medical food is a product designed to be consumed for the specific dietary management of a disease or condition. ${ }^{23}$ Medical foods are not regulated by the FDA but manufacturing of the products must comply with the FDA regulations for food. ${ }^{23}$

This review briefly discusses a few of the more popular alternatives to prescription potassium citrate. The alkalizing formulations available deserve further study. The nonalkalizing supplements were included so providers have basic knowledge of the products marketed to urolithiasis patients. Providers should use this guide as a tool for an open 
discussion with patients who may seek over-the-counter alternatives, rather than a guide for medication or supplement recommendations.

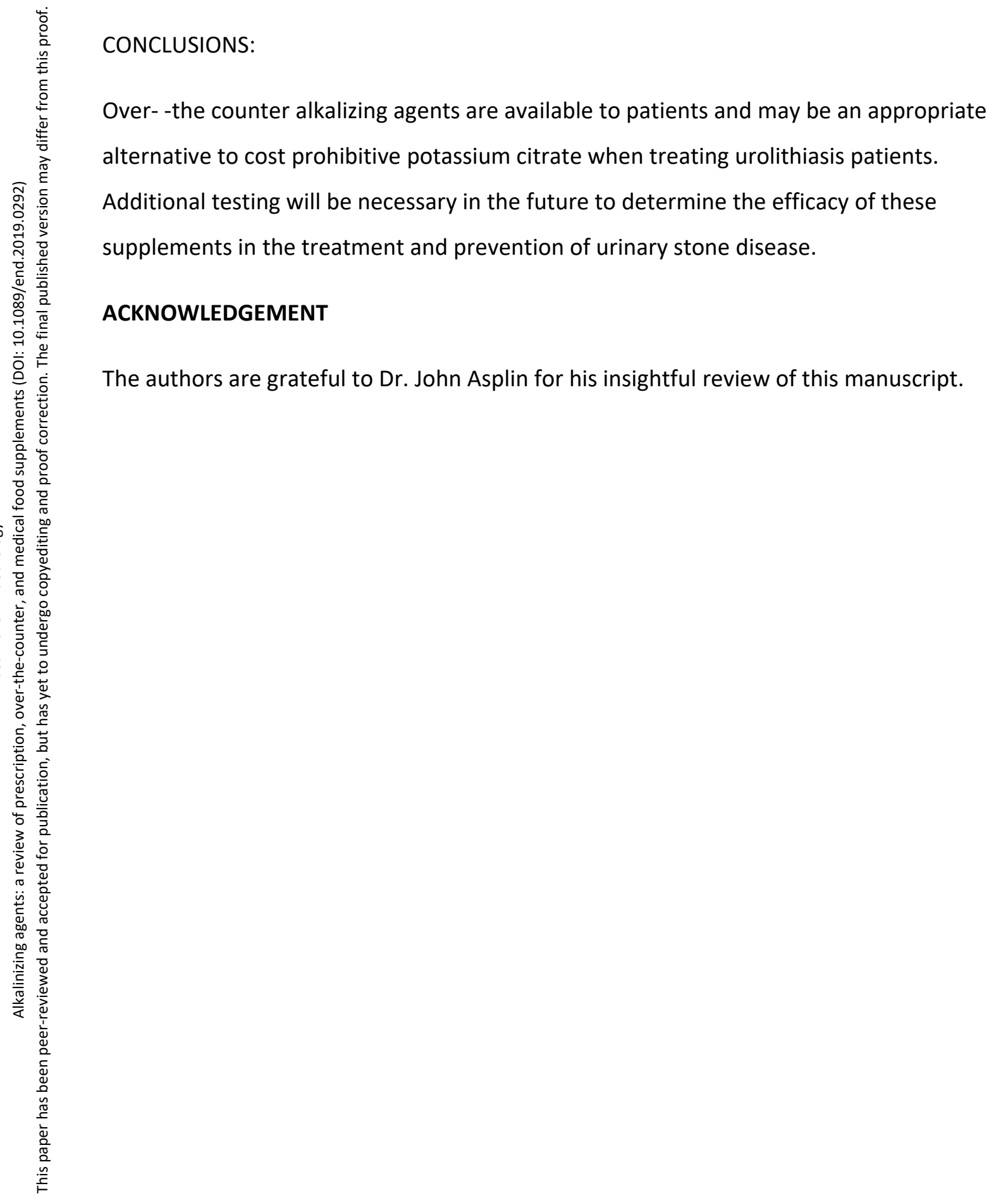


REFERENCES:

1. Scales CD Jr, Smith AC, Hanley JM, et al. Prevalence of kidney stones in the United States. Eur Urol 2012;62(1):160-5.

2. Uribarri J, Oh MS, Carroll HJ. The first kidney stone. Ann Intern Med 1989;111(12):1006-9.

3. Pearle MS, Roehrborn CG, Pak CY, et al. Meta-analysis of randomized trials for medical prevention of calcium oxalate nephrolithiasis. J Endourol 1999;13:67985.

4. Pearle MS, Goldfarb DS, Assimos DG, et al. American Urological Association. Medical management of kidney stones: AUA guideline. J Urol. 2014; 192(2):31624.

5. Ettinger B, Pak CY, Citron JT, et al. 1997. Potassium-magnesium citrate is an effective prophylaxis against recurrent calcium oxalate nephrolithiasis. J Urol 1997;158:2069-73.

6. Barcelo P, Wuhl O, Servitge E, et al. Randomized double-blind study of potassium citrate in idiopathic hypocitraturic calcium nephrolithiasis. J Urol 1993;150:1761-64.

7. Dauw CA, Yi Y, Bierlein MJ, et al. Factors associated with preventive pharmacological therapy adherence among patients with kidney stones. Urology 2016;93:45-9.

8. Zuckerman JM, Assimos DG. 2009. Hypocitrauria: pathophysiology and medical management. Reviews in Urology 2009;11(3):134-44.

9. Morgan MSC, Pearle MS. Medical management of renal stones. BMJ 2016;352:i52.

10. https://www.goodrx.com/potassiumcitrate?dosage=15meq\&form=tablet\&label override=potassium+citrate\&quantity=60. Accessed December 10, 2018. 
11. Nicar MJ, Hill K, Pak CY. Inhibition by citrate of spontaneous precipitation of calcium oxalate in vitro. J Bone Miner Res 1987; 2:215-20.

12. Meyer JL, Smith LH. Growth of calcium oxalate crystals: II. Inhibition by natural urinary crystal growth inhibitors. Invest Urol 1975; 13:36-9

13. Whittaker CF, Miklich MA, Patel RS, Fink JC. Medication Safety Principles and Practice in CKD. Clin J Am Soc Nephrol 2018;13(11):1738-1746

14. Robinson MR, Leitao VA, Haleblian GE, et al. Impact of long-term potassium citrate therapy on urinary profiles and recurrent stone formation. J Urol 2009; 181:1145-50

15. Sakhaee K, Alpern R, Poindexter J, Pak CY. Citraturic response to oral citric acid load. J Urol 1992;147(4):975-6

16. Seltzer MA, Low RK, McDonald M, et al. Dietary manipulation with lemonade to treat hypocitraturic calcium nephrolithiasis. J Urol 1996; 156:907-9.

17. Odvina CV. Comparative value of orange juice versus lemonade in reducing stone-forming risk. Clin J Am Soc Nephrol 2006; 1:1269-74.

18. Patel RM, Jiang P, Asplin J, et al. Coconut water: an unexpected source of urinary citrate. Biomed Res Int 2018; published online.

19. Eisner BH, Asplin JR, Goldfarb DS, et al. Citrate, malate and alkali content in commonly consumed diet sodas: implications for nephrolithiasis treatment. J Urol 2010; 183:2419-23.

20. Pinheiro VB, Baxmann AC, Tiselius HG, et al. The effect of sodium bicarbonate upon urinary citrate excretion in calcium stone formers. Urol 2013;82(1):33-7.

21. Sakhaee K, Alpern R, Jacobson HR, et al. Contrasting effects of various potassium salts on renal citrate excretion. J Clin Endocrinol Metab 1991;72(2):396-400

22. Phillips R, Hanchanale VS, Myatt A, et al. Citrate salts for preventing and treating calcium containing kidney stones in adults. Cochrane Database Syst Rev 2015;10:CD010057. 
23. Frequently asked questions about medical foods, $2^{\text {nd }}$ ed. 2016. https://www.fda.gov/Food/GuidanceRegulation/GuidanceDocumentsRegulator ylnformation/MedicalFoods/default.html. Accessed February 5, 2019.

24. https://www.bulksupplements.com/potassium-citrate.html . Accessed February 5, 2019.

25. https://www.nowfoods.com/supplements/potassium-citrate-powder. Accessed February 5, 2019.

26. https://litholyte.com/. Accessed February 5, 2019.

27. https://theralogix.com/products/theralith-xr-vitamin-mineral-supplement. Accessed February 5, 2019.

28. Schulsinger D, Kirshenbaum A, Sheynkin Y. 2006. Evaluation of a novel nutritional supplement to improve urinary magnesium and citrate excretion. Presented at American Urological Association Annual Conference; May 2006; Atlanta, GA.

29. https://drinkstonestop.com/?variant=9659715013. Accessed February 5, 2019.

30. https://www.ksptabs.com/. Accessed February 5, 2019.

31. https://kidneycop.com/?gclid=CjOKCQiAheXiBRDARIsAODSpWMIQxPgEp8TeQXBHJJOktEHLZhxMSEb1xNJFcVulUMFGsPVu3W6XgaAuAXEALw wcB. Accessed February 5, 2019.

32. Grases F, Isern B, Sanchis P, et al. Phytate acts as an inhibitor in formation of renal calculi. Front Biosci 2007; 12:2580-7.

33. Grases F, Rodriquez A, Costa-Bauza A. Efficacy of mixtures of magnesium, citrate and phytate as calcium oxalate crystallization inhibitors in urine. J Urol 2015; 194(3):812-9.

34. Panigrahi PN, Dey S, Sahoo M, et al. Antiurolithiatic and antioxidant efficacy of Musa paradisiaca pseudostem on ethylene glycol-induced nephrolithiasis in rat. Indian J Pharmacol 2017; 49(1): 77-83.

35. https://ampurity.com/lithobalance/. Accessed February 5, 2019. 
36. Asare GA, Bugyei K, Sittie A, et al. Genotoxicity, cytotoxicity and toxicological evaluation of whole plant extracts of the medicinal plant Phyllanthus niruri (Phyllanthaceae). Genet Mol Res 2012; 11(1):100-11.

37. Campos AH, Schor N. Phyllanthus niruri inhibits calcium oxalate endocytosis by renal tubular cells: its role in urolithiasis. Nephron 1998; 81(4)393-7.

38. Freitas AM, Schor N, Boim MA. The effect of Phyllanthus niruri on urinary inhibitors of calcium oxalate crystallization and other factors associated with renal stone formation. BJU Int 2002; 89(9)829-34.

39. Pucci ND, Marchini GS, Mazzucchi E, et al. 2018. Effect of phyllanthus niruri on metabolic parameters of patients with kidney stone: a perspective for disease prevention. IBJU 2018;44(4):758-64.

40. Fox S and Duggan M. Health online 2013. Jan 2013. http://www.pewinternet.org/2013/01/15/health-online-2013/. Accessed February 5, 2019

41. Stephens G. Taking the mystery out of medical foods. Apr 2018. https://www.nutraceuticalsworld.com/issues/2018-04/view columns/takingthe-mystery-out-of-medical-foods/50213. Accessed February 4, 2019. 
Page 18 of 22

18

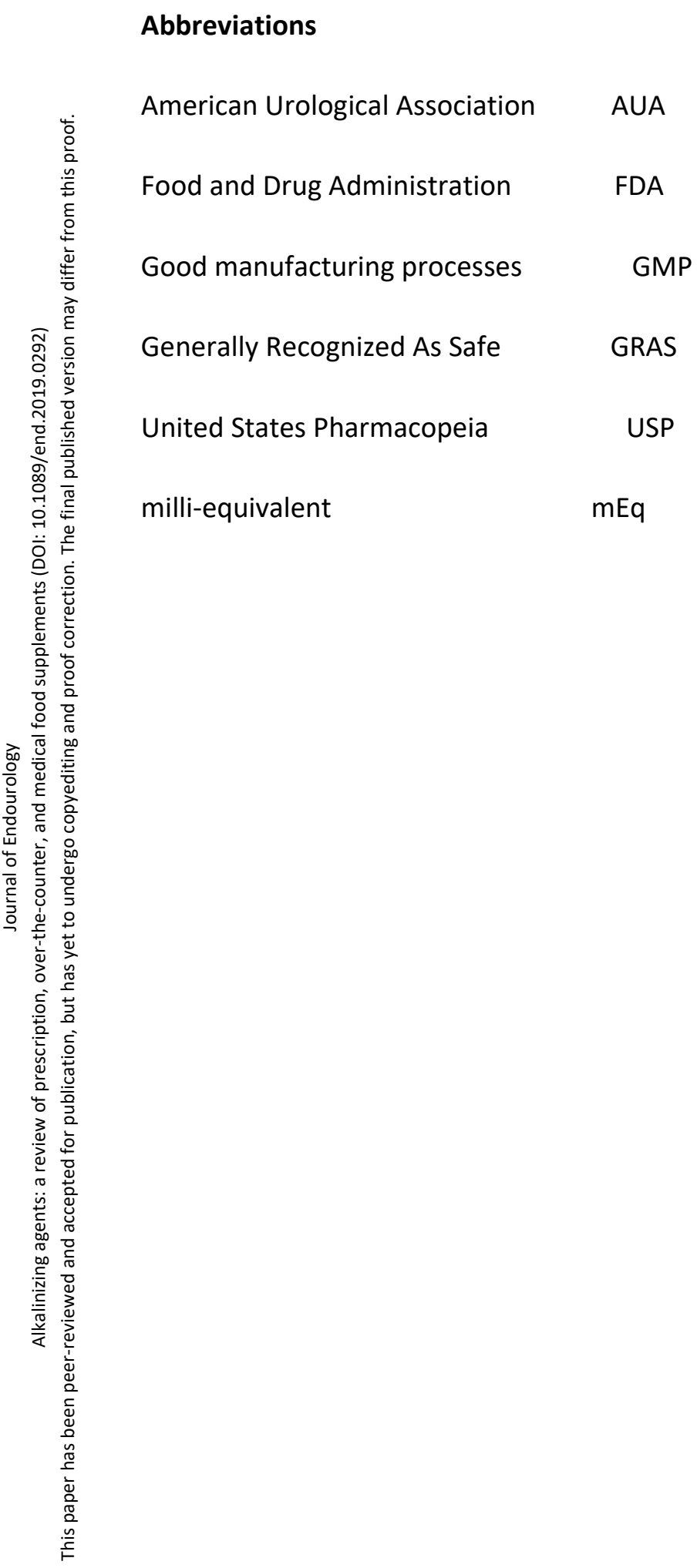


Table 1: Comparison of Potassium Citrate and Alternative Supplements ${ }^{*}$

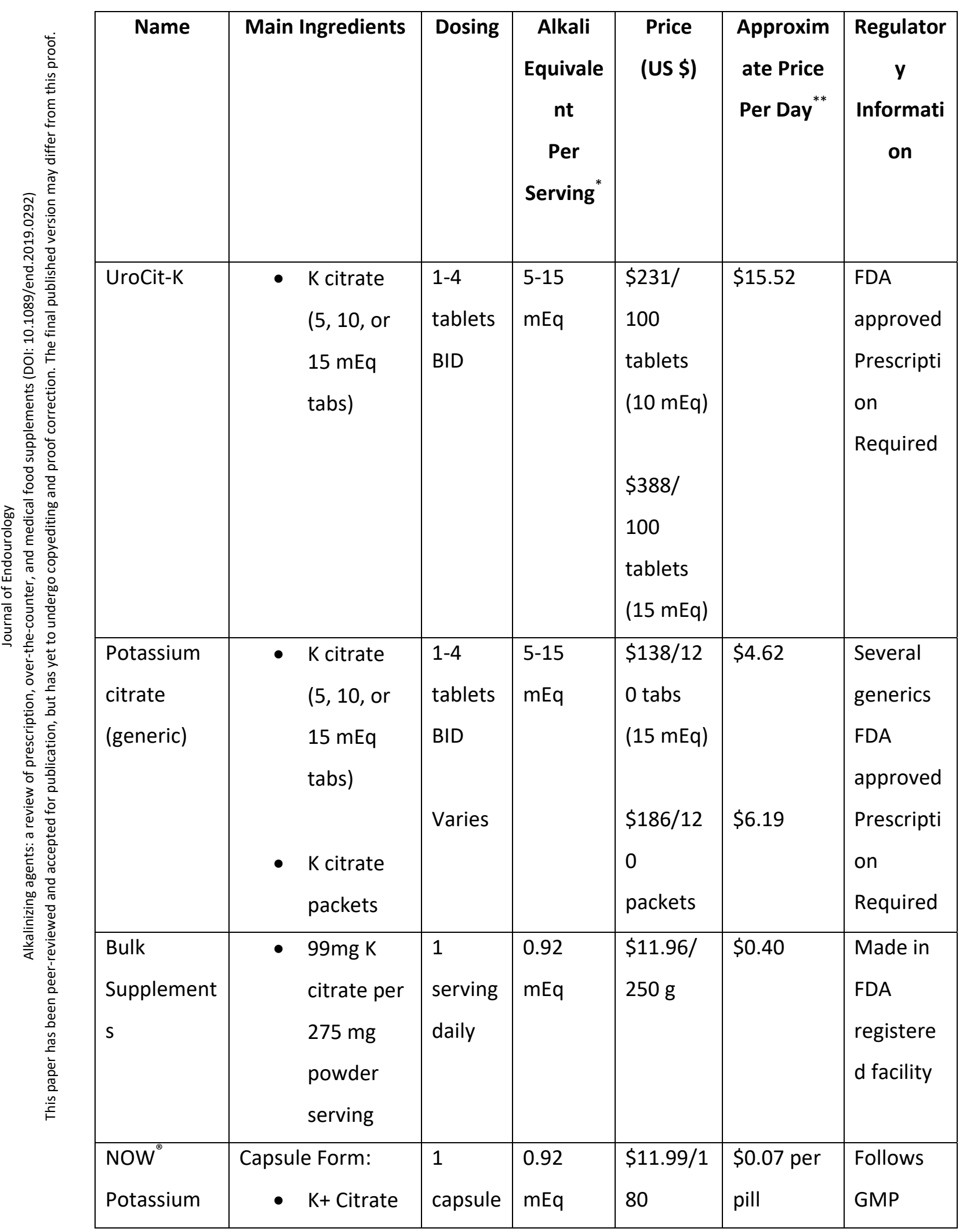




\begin{tabular}{|c|c|c|c|c|c|c|c|}
\hline 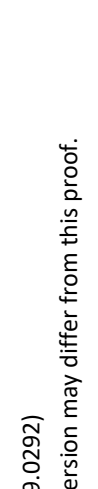 & Citrate & $\begin{array}{l}\text { (99 mg } \\
=0.9 \mathrm{mEq}) \\
\text { Powder Form: } \\
-\mathrm{K}+\text { Citrate } \\
(448 \mathrm{mg}=4 \\
\mathrm{mEq}) 1.4 \\
\text { gm }\end{array}$ & $\begin{array}{l}1-5 x \\
\text { daily } \\
1 / 4 \\
\text { teaspo } \\
\text { on } 1-2 x \\
\text { daily }\end{array}$ & $\begin{array}{l}4.15 \\
\mathrm{mEq}\end{array}$ & $\begin{array}{l}\text { capsules } \\
\$ 12.99 / 1 \\
2 \text { ounces }\end{array}$ & & \\
\hline 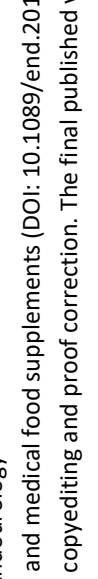 & Litholyte $^{\circledast}$ & $\begin{array}{ll}\text { - } & \text { K+ Citrate } \\
& (4 \mathrm{mEq}) \\
\text { - } & \text { Mg Citrate } \\
& (2.5 \mathrm{mEq}) \\
\text { - } & \mathrm{Na} \\
\text { Bicarbonat } \\
\mathrm{e}(3.5 \\
\mathrm{mEq})\end{array}$ & $\begin{array}{l}1-2 \\
\text { packets } \\
\text { BID }\end{array}$ & $10 \mathrm{mEq}$ & $\begin{array}{l}\$ 30 / 60 \\
\text { packets }\end{array}$ & $\$ 1.00$ & $\begin{array}{l}\text { Follows } \\
\text { GMP }\end{array}$ \\
\hline 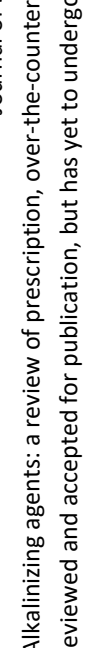 & $\begin{array}{l}\text { TheraLith } \mathrm{X} \\
\mathrm{R}\end{array}$ & $\begin{array}{l}\text { - } \mathrm{B6} \text { (7.5mg) } \\
\text { Mg } \\
\text { citrate+oxi } \\
\text { de (180 mg } \\
=1.2 \mathrm{mEq} \\
\text { Mg citrate) } \\
\text { K+ Citrate } \\
\text { (99 mg= } \\
0.9 \mathrm{mEq})\end{array}$ & $\begin{array}{l}2 \text { tabs } \\
\text { BID }\end{array}$ & $\begin{array}{l}2.12 \\
\mathrm{mEq}\end{array}$ & $\begin{array}{l}\$ 60 / \text { bott } \\
\text { le }(360 \\
\text { tabs) }\end{array}$ & $\$ 0.67$ & $\begin{array}{l}\text { Follows } \\
\text { GMP }\end{array}$ \\
\hline 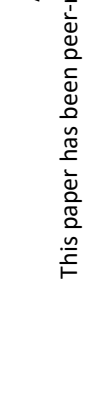 & $\begin{array}{l}\text { Kidney } \\
\text { C.O.P. }\end{array}$ & 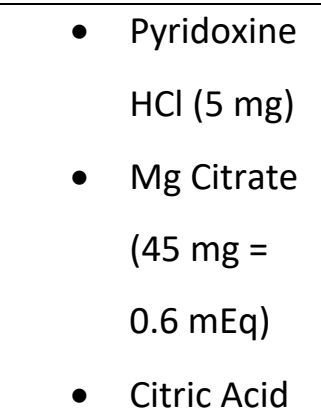 & $\begin{array}{l}2 \text { tabs } \\
\text { daily }\end{array}$ & $5.1 \mathrm{mEq}$ & $\begin{array}{l}\$ 29.95 / \\
\text { bottle } \\
\text { (60 } \\
\text { capsules) }\end{array}$ & $\$ 1.00$ & $\begin{array}{l}\text { GRAS } \\
\text { Follows } \\
\text { GMP }\end{array}$ \\
\hline
\end{tabular}




\begin{tabular}{|c|c|c|c|c|c|c|}
\hline & $\begin{array}{l}\text { (350 mg } \\
=4.5 \mathrm{mEq}) \\
-\quad \text { Phytin } \\
\text { (Inositol) } \\
\text { (200 mg) } \\
-\quad \text { Musa } \\
\text { Paradisiac } \\
\text { a (200 mg) }\end{array}$ & & & & & \\
\hline 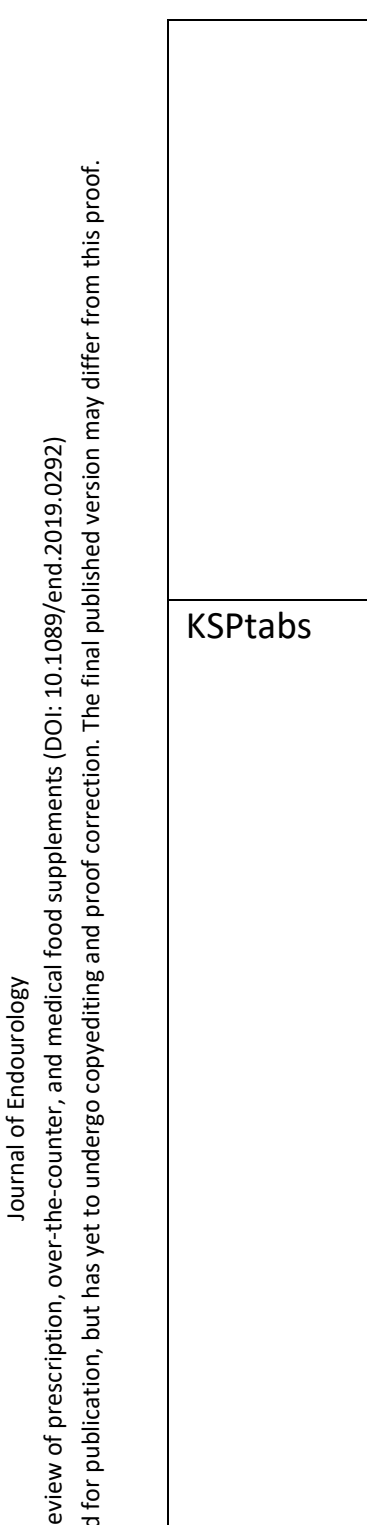 & $\begin{array}{ll}\text { - } & \text { B6 (7.5 } \\
\text { mg) } \\
\text { - } \mathrm{Mg}(64 \mathrm{mg} \\
=0.9 \mathrm{mEq} \\
\mathrm{Mg} \text { citrate) } \\
\text { - } \mathrm{Na} \\
\text { Bicarbonat } \\
\text { e (170 mg } \\
=2 \mathrm{mEq}) \\
\text { K+ } \\
\text { Bicarbonat } \\
\text { e (100 mg } \\
=1 \mathrm{mEq})\end{array}$ & $\begin{array}{l}2-3 \\
\text { tabs } \\
\text { Daily }\end{array}$ & $\begin{array}{l}2.92 \\
\mathrm{mEq}\end{array}$ & $\begin{array}{l}\$ 59.95 / 8 \\
0 \text { tabs }\end{array}$ & $\$ 1.50$ & \\
\hline 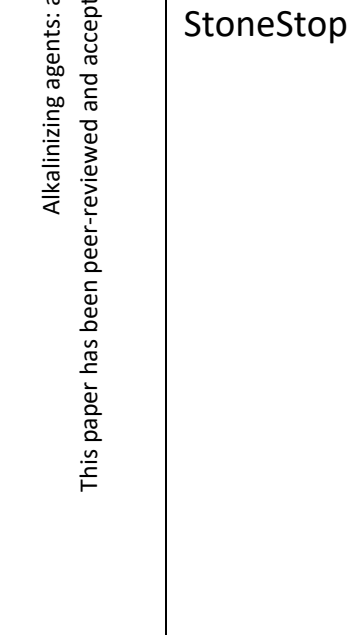 & $\begin{array}{ll}\text { - } & \text { Citrate } \\
\text { - } & \text { Magnesiu } \\
\text { m } \\
\text { - } \text { B6 } \\
\text { No } \\
\text { informatio } \\
\text { n on alkali } \\
\text { equivalent } \\
\text { s or }\end{array}$ & $\begin{array}{l}2 \\
\text { packets } \\
\text { daily }\end{array}$ & $\begin{array}{l}\text { Unknow } \\
\text { n }\end{array}$ & $\begin{array}{l}\$ 29.99 / 3 \\
0 \\
\text { packets }\end{array}$ & $\$ 2.00$ & $\begin{array}{l}\text { Follows } \\
\text { GMP }\end{array}$ \\
\hline
\end{tabular}




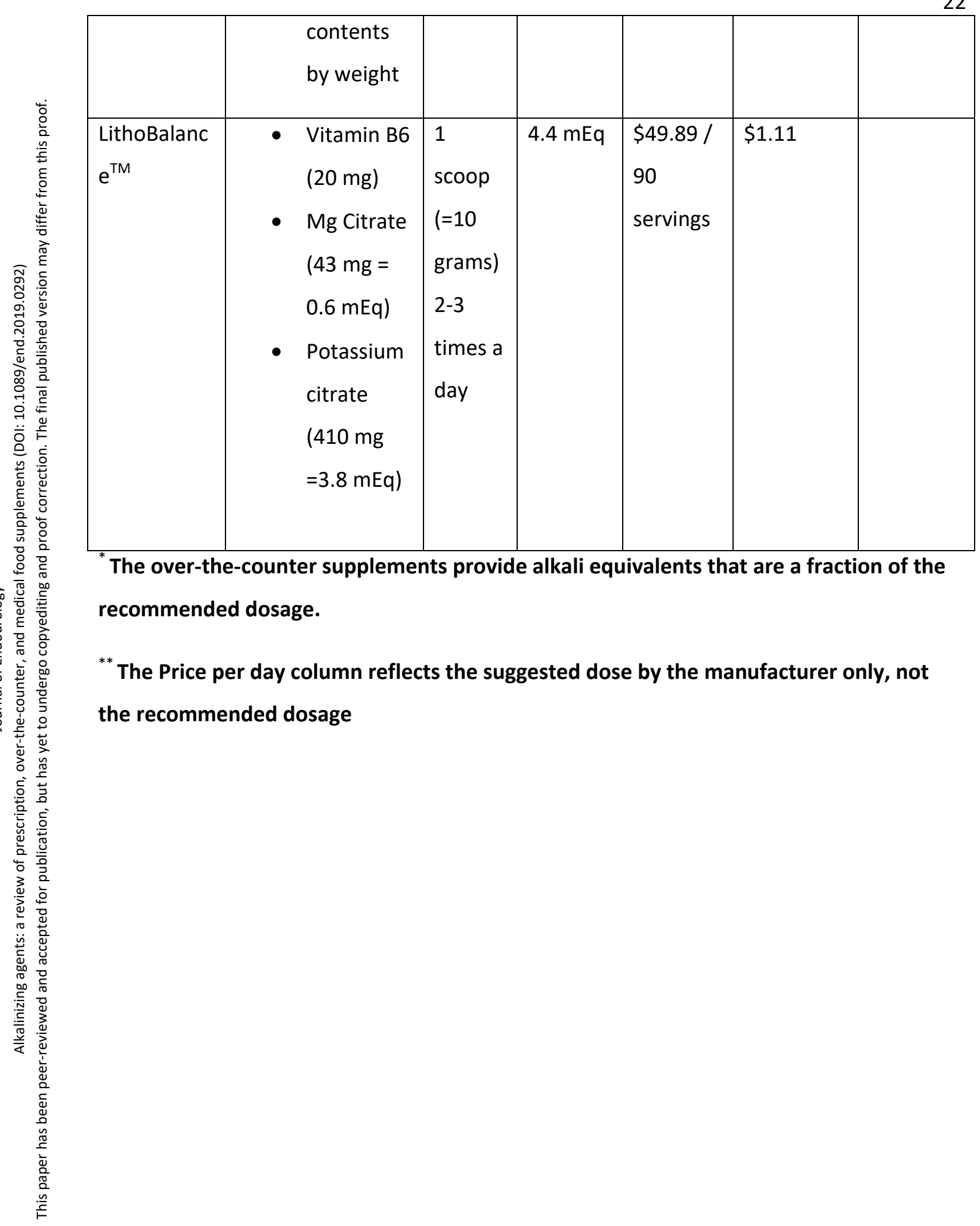

